\title{
PENERAPAN MODEL PEMBELAJARAN MAKE A MATCH UNTUK MENINGKATKAN PERKEMBANGAN KOGNITIF DALAM MENGENAL LAMBANG BILANGAN
}

\author{
Ni Md Desy Pratiwi Handaryani 1, I Ketut Pudjawan², \\ 1 Jurusan Pendidikan Guru Pendidikan Anak Usia Dini \\ 2 Jurusan Teknologi Pendidikan \\ Universitas Pendidikan Ganesha, Singaraja, Indonesia \\ e-mail: desiipratiwi94@gmail.com ${ }^{1}, \underline{\text { ketutpudjawan@gmail.com }}^{2}$
}

\begin{abstract}
Abstrak
Penelitian ini adalah penelitian tindakan kelas yang bertujuan untuk mengetahui peningkatan perkembangan kognitif dalam mengenal lambang bilangan setelah diterapkan model pembelajaran make a match pada anak kelompok A1 TK Kartika VII-3 Singaraja. Penelitian ini adalah penelitian tindakan kelas (PTK) yang dilaksanakan dalam dua siklus tindakan. Subjek penelitian ini adalah siswa kelompok A1 TK Kartika VII-3 Singaraja Tahun Pelajaran 2018/2019 yang berjumlah 18 orang siswa, yang terdiri dari 8 orang anak perempuan dan 10 orang anak laki-laki. Metode analisis yang digunakan adalah metode analisis statistik deskriptif dan metode analisis deskriptif kuantitatif. Hasil analisis data pada penelitian ini menunjukkan bahwa terjadi peningkatan rata-rata persentase perkembangan kognitif dalam mengenal lambang bilangan pada anak kelompok A1 sebesar $15,25 \%$. Hal ini dapat dilihat dari adanya peningkatan rata-rata persentase perkembangan kognitif dalam mengenal lambang bilangan anak pada siklus I sebesar $65,25 \%$ dengan kriteria sedang menjadi $80,50 \%$ pada siklus II dengan kriteria tinggi. Dengan demikian, dapat disimpulkan bahwa penerapan model pembelajaran make a match dapat meningkatkan perkembangan kognitif dalam mengenal lambang bilangan anak Kelompok A1 TK Kartika VII-3 Singaraja Tahun Pelajaran 2018/2019.
\end{abstract}

Kata Kunci: Make a match, Perkembangan Kognitif, Lambang Bilangan

\begin{abstract}
This research is a classroom action research which aims to determine the improvement of cognitive development in recognizing the number symbol after applying the make a match learning model to the children of A1 TK Kartika VII-3 Singaraja group. This research is classroom action research (CAR) which is carried out in two action cycles. The subjects of this study were students of A1 group TK Kartika VII-3 Singaraja in 2018/2019 Academic Year which consisted of 18 students, consisting of 8 girls and 10 boys. The analytical method used is descriptive statistical analysis method and quantitative descriptive analysis method. The results of data analysis in this study indicate that there is an increase in the average percentage of cognitive development in recognizing the symbol of numbers in children in group A1 of $15.25 \%$. This can be seen from the increase in the average percentage of cognitive development in recognizing the symbol of child numbers in the first cycle of $65.25 \%$ with the criteria being medium to $80.50 \%$ in cycle II with high criteria. Thus, it can be concluded that the application of the make a match learning model can improve cognitive development in recognizing the symbolic number of children in Group A1 TK Kartika VII-3 Singaraja Academic Year 2018/2019
\end{abstract}

Keywords: Make a match, Cognitive Development, Number Symbols 


\section{Pendahuluan}

"Anak usia dini ialah anak usia 0-6 tahun yang memiliki pertumbuhan dan perkembangan luar biasa sehingga memunculkan keunikan pada dirinya" (Fadlillah, 2012:19). Pada usia ini proses pertumbuhan dan perkembangan dalam berbagai aspek sedang mengalami masa yang cepat dalam rentang perkembangan hidup manusia. Pemberian stimulasi, rangsangan atau pengalaman kepada anak dapat memicu keberhasilan setiap aspek perkembangan anak. Semakin sering anak diberikan suatu rangsangan ataupun latihan-latihan maka akan menjadi suatu kebiasaan. Menanamkan nilai-nilai kebaikan yang nantinya dapat membentuk kepribadian anak sangat tepat dilakukan pada usia ini. Proses pembelajaran sebagai bentuk perlakuan yang diberikan pada anak harus memperhatikan karakteristik yang dimiliki dalam setiap tahapan perkembangan anak. Menurut Yusuf dan Sugandhi (2012:9), "perkembangan manusia berlangsung secara berurutan atau berkesinambungan melalui periode atau masa. Periode itu terdiri atas tiga periode, yaitu anak, remaja dan dewasa."

"Pendidikan anak usia dini merupakan suatu upaya pembinaan yang ditujukan bagi anak sejak lahir dengan memberikan rangsangan pendidikan untuk membantu pertumbuhan dan perkembangan jasmani serta rohani agar anak memiliki kesiapan dalam memasuki pendidikan lebih lanjut" (Mulyasa, 2012:48). Salah satu cara yang dapat dilakukan adalah dengan memberikan kesempatan pada anak untuk memperoleh pengalaman belajar dari lingkungan melalui pengamatan, meniru, dan bereksperimen yang berlangsung berulang-ulang dan melibatkan seluruh potensi dan kecerdasan anak. Menurut Fadlillah (2012:73), "pendidikan bagi anak usia dini berfungsi untuk mengembangkan seluruh kemampuan yang dimiliki anak sesuai dengan tahap perkembangannya, mengenalkan anak dengan dunia sekitar, serta memberikan kesempatan pada anak menikmati masa bermainnya." Pada usia ini berbagai pertumbuhan serta perkembangan mulai dan sedang berlangsung, seperti perkembangan fisik (koordinasi motorik halus dan kasar), kognitif, bahasa, sosioemosinal serta nilai agama dan moral.

Setiap anak memiliki karakteristik yang berbeda-beda sesuai dengan tahap usianya. Oleh karena itu pendidikan anak usia dini hendaknya dilaksanakan melalui bermain. Hal ini sesuai dengan karakteristik anak yang bersifat aktif dalam mengeksplorasi lingkungannya. Bermain merupakan bagian dari proses pembelajaran pada anak usia dini. Kegiatan bermain yang dilakukan oleh anak diarahkan pada pengembangan kemampuan yang dimilikinya. Oleh karena itu pembelajaran pada anak usia dini harus dirancang agar anak tidak merasa dibebani.

Perkembangan anak usia dini merupakan masa saat semua aspek dalam dirinya sedang mengalami pertumbuhan dan perkembangan. Pemberian stimulasi, rangsangan atau pengalaman kepada anak juga dapat menjadi pemicu keberhasilan dalam perkembangan anak. Salah satu aspek perkembangan yang dikembangkan di PAUD adalah kemampuan kognitif.

Kemampuan kognitif sebagai salah satu kemampuan dasar dalam upaya mengembangkan kemampuan berpikir anak. Perkembangan kognitif menunjukkan perkembangan dari cara anak berpikir serta kemampuan anak untuk menyelesaikan suatu masalah. Perkembangan kognitif menyebutkan bahwa anak prasekolah merupakan bagian dari pra-operasional (2-7 tahun) adalah fungsi simbolik.

Perkembangan kognitif memiliki pengertian yang luas, salah satu perkembangan kognitif yang harus dimiliki oleh anak adalah anak memahami konsep bilangan yang sering anak lihat sehari-hari di lingkungannya. Menurut Tarigan (2006:15), "dalam kehidupan sehari-hari bilangan sering dijumpai dalam kehidupan manusia bahkan merupakan kebutuhan dasar manusia dari semua lapisan pergaulan hidup sehari-hari." Adanya bilangan membantu manusia untuk melakukan banyak perhitungan, mulai dari yang sederhana sampai kepada perhitungan yang rumit. Mengingat pentingnya konsep bilangan dalam kehidupan sehari-hari, 
maka pengetahuan tentang bilangan perlu dikenalkan kapada anak sedini mungkin, dengan cara kaidah yang benar.

Guru mempunyai peranan penting untuk memberikan sebuah pendidikan di sekolah, guru haruslah memiliki kualitas dan pendidikan yang baik. Menurut Wiyani (2014:20), "kesiapan guru PAUD tidak hanya semangat saja tetapi ternyata semangat saja tidaklah cukup, mengingat banyak pengetahuan dan keterampilan yang dibutuhkan bagi seorang pendidik". Kesalahan dalam memberikan stimulasi pada anak usia dini karena dasar kurangnya pengetahuan semestinya dapat diantisipasi dengan memberikan pengetahuan dan keterampilan awal bagi mereka guru PAUD yang akan berkecimpung di dunia anak.

Menurut Carolin (2014:2), "mengenal konsep bilangan termasuk dalam kemampuan berhitung permulaan pada anak usia dini". Besar sekali pengaruh pemahaman konsep bilangan untuk anak. Melalui pemahaman konsep bilangan, anak lebih mudah memahami dan mempelajari matematika tingkat selanjutnya. Sebelum anak mengenal konsep bilangan, maka anak tidak dapat melanjutkan kemampuan yang lainnya seperti, berhitung penjumlahan yang nantinya sangat berguna dalam kehidupan sehari-hari. Jadi, mengenal konsep bilangan merupakan modal awal bagi anak untuk memahami dasar-dasar pembelajaran matematika yang dapat membantu anak dalam kehidupan sehari-hari.

Berdasarkan hasil observasi yang dilakukan di TK Kartika VII-3 Singaraja pada anak kelompok $A 1$ yang berjumlah 18 oarang anak. Kemampuan mengenal lambang bilangan pada 13 orang anak belum berkembang dengan optimal. Hal tersebut disebabkan oleh 2 permasalahan yang ditemui saat melakukan observasi dan wawancara dengan guru. Pertama, 5 orang anak belum mampu menyebutkan angka secara urut dengan mandiri. Misalkan 1, 2, 4, 5, 7, dst. Kedua, 8 orang anak sudah mampu menyebutkan dengan urutan yang benar tetapi jika angka tersebut diacak anak menjadi bingung. Ketiga, anak masih memerlukan bantuan untuk menghitung jumlah benda atau gambar yang ada.

Guru memiliki peran yang sangat penting dalam menentukan metode maupun model pembelajaran yang akan digunakan dan disesuaikan dengan keadaan, kebutuhan serta kemampuan anak. Salah satu alternatif yang dapat dilakukan untuk mengatasi permasalahan tersebut adalah dengan menggunakan model pembelajaran kooperatif tipe make a match. Pemilihan model pembelajaran yang tepat untuk diterapkan pada anak usia dini dapat menentukan keberhasilan dalam mengembangkan kemampuan kgnitif anak terutama dalam mengenal lambang bilangan. Menurut Ngalimun (2013:27), "model pembelajaran adalah suatu perencanaan atau suatu pola yang digunakan sebagai pedoman dalam merencanakan pembelajaran di dalam kelas." Menciptakan suasana yang aman, nyaman, dan menarik untuk anak serta menerapkan pembelajaran yang berpusat pada anak dan dilaksanakan secara menyenangkan.

Model pembelajaran make a match merupakan salah satu model pembelajaran kooperatif yang menuntut siswa lebih aktif dalam proses pembelajaran dan mampu bekerjasama dalam kelas. Menurut Kurniasih \& Sani (2013:55) "make a match adalah model pembelajaran yang melibatkan siswa untuk mencari pasangan sambil belajar mengenai suatu konsep atau topik dalam suasana yang menyenangkan." Mengenal lambang bilangan melalui penerapan model pembelajaran make a match memberikan kesempatan pada anak meningkatkan partisipasi dan kreatifitasnya. Anak akan terlatih untuk mencari pasangan kartu jawaban atau soal yang diberikan guru dalam mengembangkan kemampuan mengenal lambang bilangan. Kegiatannya pun dapat diakukan melalui bermain sehingga anak tidak akan merasa jenuh.

Berdasarkan latar belakang tersebut, maka dibuat rancangan penelitian yang berjudul "Penerapan Model Pembelajaran Make A Match Untuk Meningkatkan Perkembangan Kognitif Dalam Mengenal Lambang Bilangan Pada Anak Kelompok A1 TK Kartika VII-3 Singaraja." 


\section{Metode}

Penelitian ini dilaksanakan di Kelompok A1 TK Kartika VII-3 Singaraja yang terletak di jalan Pahlawan No 40, Singaraja. Penelitian ini dilaksanakan pada Semester I Tahun Pelajaran 2018/2019. Penelitian ini dilaksanakan dalam dua siklus. Setiap siklus dalam penelitian ini terdiri dari empat tahapan yaitu tahap perencanaan, tahap pelaksanaan, pengamatan, dan refleksi.

Subjek dalam penelitian ini adalah anak kelompok A1 di TK Kartika VII-3 Singaraja, dengan jumlah anak 18 orang, yang terdiri dari 8 orang anak perempuan dan 10 orang anak laki-laki. Objek dalam penelitian ini adalah perkembangan kognitif dalam mengenal lambang bilangan terkait penerapan model pembelajaran make a match pada anak kelompok A1 TK Kartika VII-3 Singaraja.

Penelitian ini tergolong penelitian tindakan kelas (PTK). Pada hakikatnya PTK merupakan penelitian yang bertujuan untuk melakukan perbaikan terhadap proses pembelajaran. Terkait dengan hal tersebut, menurut Sanjaya (2011:26), "penelitian tindakan kelas merupakan proses pengkajian masalah pembelajaran di dalam kelas melalui refleksi diri dalam upaya untuk memecahkan masalah dengan melakukan berbagai tindakan yang terencana dalam situasi nyata." Menurut Trianto (2011:16), "penelitian tidakan kelas merupakan suatu penelitian dengan mencermati kegiatan pembelajaran yang diberikan tindakan, dengan tujuan untuk memecahkan masalah atau meningkatkan mutu pembelajaran di kelas tersebut." Menurut Arikunto, dkk. (2015:1) "penelitian tindakan kelas merupakan suatu pencermatan terhadap kegiatan belajar berupa sebuah tindakan yang sengaja dimunculkan dan terjadi dalam sebuah kelas secara bersama." Berdasarkan pendapat tersebut dapat disimpulkan bahwa, penelitian tindakan kelas merupakan penelitian yang dilakukan guru untuk mengkaji masalah pembelajaran melalui refleksi diri, memperbaiki strategi dalam kegiatan proses belajar mengajar dengan memberikan sebuah tindakan. Adapun tindakan yang dilakukan dalam penelitian tindakan kelas ini adalah penerapan model pembelajaran make a match untuk meningkatkan perkembangan kognitif dalam mengenal lambang bilangan pada anak kelompok A1 TK Kartika VII-3 Singraja.

Penelitian ini merupakan penelitian tindakan kelas yang dirancang dalam siklus tindakan. Setiap siklus dalam penelitian tindakan kelas ini terdiri dari empat tahapan penting yaitu perencanaan, pelaksanaan, pengamatan, dan refleksi. Apabila penelitian tindakan kelas ini disajikan dalam bentuk gambar akan tampak sebagai berikut.

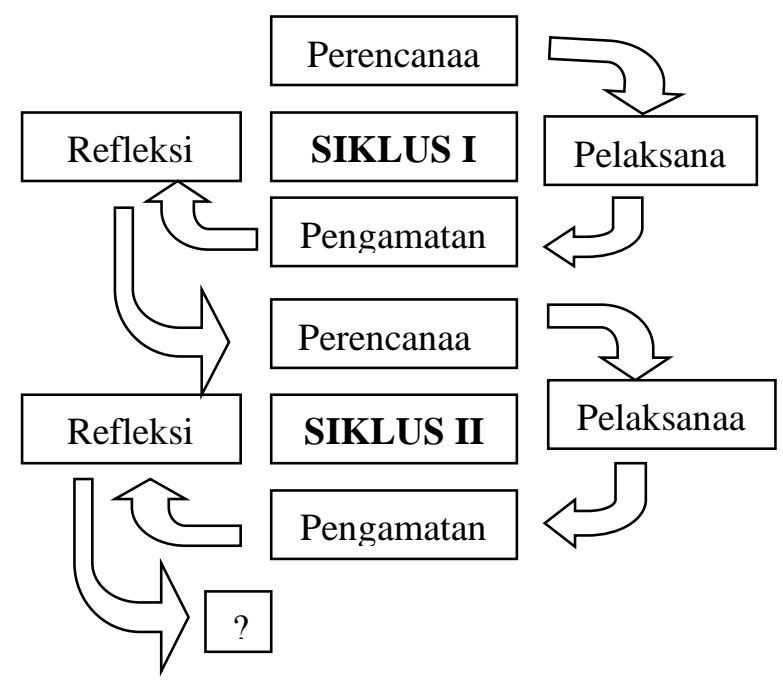

Gambar 01. Gambar Rancangan Penelitian Tindakan Kelas (Sumber: Arikunto, dkk. 2015:42) 
(1) Perencanaan Tindakan. Pada tahap perencanaan tindakan ini menjelaskan tentang apa, mengapa, kapan, dimana, oleh siapa, dan bagaimana tindakan tersebut dilakukan. Dalam tahap menyususn perencanaan ini ditentukan titik atau fokus peristiwa yang perlu mendapatkan perhatian khusus untuk diamati. Menentukan tingkat capaian perkembangan anak, menyusun peta konsep, menyusun rencana pelaksanaan pembelajaran mingguan (RPPM), menyusun rencana pelaksanaan pembelajaran harian (RPPH), serta instrumen penilaian. (2) Pelaksanaan Tindakan. Pelaksanaan merupakan implementasi atau penerapan isi rancangan yaitu mengenai tindakan di kelas. Kegiatan yang dilakukan dalam tahap ini adalah melaksanakan kegiatan yang telah dirumuskan dalam rancangan tindakan. (3) Pengamatan. Kegiatan pengamatan yang dilakukan pada saat tindakan sedang dilakukan. Kegiatan yang dilakukan pada rancangan pengamatan ini adalah mengamati perkembangan kognitif dalam mengenal lambang bilangan pada anak setelah diterapkannya model pembelajaran make a match. Pengamatan dilakukan secara langsung saat melaksanakan kegiatan pembelajaran agar memperoleh data yang akurat. (4) Refleksi. Kegiatan refleksi merupakan kegiatan untuk mengemukakan kembali apa yang sudah dilakukan. Kegiatan refleksi ini dilakukan untuk melihat kekurangan dan kelebihan dalam kegiatan pembelajaran menggunakan model pembelajaran make a match. Kemudian merangkum kendala-kendala selama melakukan tindakan dan mencari solusi untuk mengatasi kendala tersebut.

Untuk mengumpulkan data dalam suatu penelitian diperlukan suatu metode untuk memperoleh data yang akurat. Metode pengumpulan data dalam penelitian ini menggunakan metode observasi. Menurut Hasan (2003:17) pengamatan atau observasi adalah cara pengumpulan data dengan terjun langsung dan melihat langsung ke lapangan terhadap objek yang diteliti. Sedangkan menurut Sukardi (2012:78) observasi adalah instrumen yang sering dijumpai dalam penelitian pendidikan. Instrumen observasi akan lebih efektif jika informasi yang hendak diambil berupa kondisi atau fakta alami, tingkah laku dan hasil kerja responden dalam situasi alami. Metode observasi merupakan cara memperoleh data yang lebih dominan menggunakan indera penglihatan (mata) dalam proses pengukuran terhadap suatu objek. Dalam penelitian ini, metode observasi digunakan untuk mengumpulkan data perkembangan kognitif dalam mengenal lambang bilangan.

Instrumen yang digunakan dalam penelitian ini adalah lembar observasi. Observasi dilakukan terhadap kegiatan peneliti dan anak dalam menerapkan model pembelajaran make a match. Menurut Dimyati (2013:96) setiap kegiatan yang diobservasikan dikategorikan ke dalam kualitas yang sesuai dengan kemampuan anak yaitu anak belum berkembang dengan tanda bintang satu ( $\star$ ), anak mulai berkembang dengan tanda bintang dua ( $\star \star)$, anak berkembang sesuai harapan dengan tanda bintang tiga $(\star \star \star)$, anak mampu lebih dari harapan dengan tanda bintang empat $(\star \star \star \star)$. Pedoman observasi merupakan alat yang digunakan untuk acuan pengamatan, untuk mengetahui sejauh mana peningkatan perkembangan kognitif dalam mengenal lambang bilangan. Pedoman observasi disusun untuk memudahkan dalam melakukan pengamatan terhadap proses pembelajaran.

Setelah data dalam penelitian ini terkumpul maka selanjutnya dilakukan analisis data. Dalam penelitian ini menggunakan metode analisis statistik deskriptif dan metode analisis deskriptif kuantitatif.

Metode Analisis Statistik Deskriptif adalah suatu cara pengolahan data yang dilakukan dengan jalan menyusun secara sistematis dalam bentuk angka-angka atau persentase, mengenai suatu objek yang diteliti sehingga diperoleh kesimpulan umum (Agung, 2014:110). Dalam penerapan metode analisis statistik deskripif, data yang diperoleh dari hasil penelitian disajikan ke dalam tabel distribusi frekuensi, menghitung angka rata-rata atau mean (M), menghitung modus (Mo), menghitung median (Me), menyajikan ke dalam grafik. 
Metode analisis deskriptif kuantitatif adalah suatu cara pengolahan data yang di lakukan dengan jalan menyusun secara sistematis dalam bentuk angka-angka atau persentase mengenai keadaan suatu objek yang diteliti, sehingga diperoleh kesimpulan umum (Agung, 2014:110). Metode analisis deskriptif kuantitatif ini digunakan untuk menentukan tinggi rendah data perkembangan kognitif dalam mengenal lambang bilangan yang ditentukan dengan menggunakan pedoman konversi Penilaian Acuan Patokan (PAP) skala lima.

Tingkat perkembangan kognitif dalam mengenal lambang bilangan yang diperoleh anak hasilnya dikonversikan dengan cara, membandingkan angka rata-rata persen dengan kriteria penilaian acuan patokan (PAP) skala 5 sebagai berikut.

Tabel 01. Tabel Pedoman Konversi PAP Skala Lima tentang Tingkat Perkembangan Kognitif dalam mengenal lambang bilangan

\begin{tabular}{|c|c|}
\hline $\begin{array}{c}\text { Persentase } \\
\text { perkembangan } \\
\text { kognitif dalam } \\
\text { mengenal lambang } \\
\text { bilangan }\end{array}$ & $\begin{array}{c}\text { Kriteria } \\
\text { perkembangan } \\
\text { kognitif dalam } \\
\text { mengenal lambang } \\
\text { bilangan }\end{array}$ \\
\hline $90-100$ & $\begin{array}{c}\text { Sangat Tinggi } \\
80-89\end{array}$ \\
$65-79$ & Tinggi \\
$55-64$ & Sedang \\
$0-54$ & Rendah \\
\hline
\end{tabular}

(Sumber: Agung, 2014:145)

Kriteria keberhasilan pada penelitian ini adalah adanya peningkatan dalam perkembangan kognitif dalam mengenal lambang bilangan pada anak kelompok A1 TK Kartika VII-3 Singaraja. Penelitian ini dinyatakan berhasil jika terjadi peningkatan skor rata-rata dari siklus I ke siklus II dan jika dikonversikan pada pedoman PAP Skala lima tentang tingkat perkembangan kognitif dalam mengenal lambang bilangan anak berada pada rentang 80-89 dengan kriteria tinggi.

\section{Hasil dan Pembahasan \\ Hasil}

Penelitian tindakan kelas ini dilaksanakan pada anak kelompok A1 TK Kartika VII-3 Singaraja Tahun Pelajaran 2018/2019 dengan jumlah subjek sebanyak 18 anak yang terdiri dari 8 orang anak perempuan dan 10 orang anak laki-laki. Penelitian ini dilaksanakan dalam II siklus. Tema yang digunakan pada saat penelitian ini berlangsung, mengikuti tema yang diterapkan oleh sekolah yaitu tema binatang. Data yang dikumpulkan adalah data tentang perkembangan kognitif dalam mengenal lambang bilangan anak seletah diterapkan model pembelajaran make a match. Data tersebut dianalisis dengan menggunakan metode analisis statistik deskriptif dan metode analisis deskriptif kuantitatif. Kegiatan penelitian ini dilaksanakan pada bulan September - Oktober 2018.

Pada siklus I dilaksanakan mulai dari tanggal 24 Setember 2018 sampai 27 September 2018 yang dilaksanakan dalam 4 kali pertemuan. Pelaksanaan siklus I ini dilaksanakan berdasarkan perencanaan pelaksanaan pembelajaran yang telah dibuat sebelumnya. Mulai dari membuat Rencana Pelaksanaan Pembelajaran Mingguan serta Rencana Pelaksanaan Pembelajaran Harian. Adapun tema pada siklus I ini adalah Tema Binatang.

Berdasarkan hasil analisis data yang disajikan dalam grafik polygon menunjukkan bahwa Modus < Median < Mean $(9<10<10,44)$, sehingga dapat dikatakan bahwa sebaran data-data 
perkembangan kognitif dalam mengenal lambang bilangan pada siklus I merupakan kurva juling positif. Dengan demikian dapat diinterpretasikan bahwa skor perkembangan kognitif dalam mengenal lambang bilangan pada anak kelompok A1 di TK Kartika VII-3 Singaraja cenderung rendah. Apabila digambarkan dalam bentuk grafik polygon akan tampak sebagai berikut.

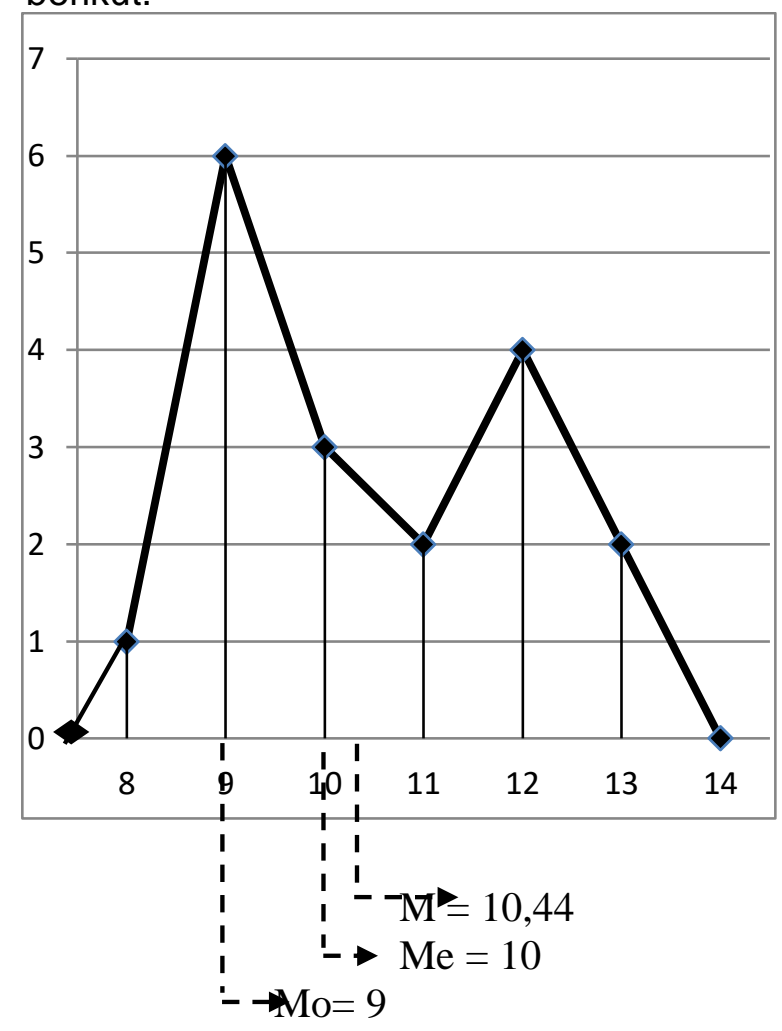

Gambar 4.1 Grafik Data Perkembangan Kognitif Dalam Mengenal Lambang Bilangan Siklus I

Sedangkan untuk menghitung tingkat perkembangan kognitif dalam mengenal lambang bilangan anak dapat dihitung dengan membandingkan rata-rata persentase (M\%) dengan Kriteria Pedoman Acuan Patokan (PAP) skala lima. Nilai M\%=65,25\% yang dikonversikan kedalam PAP skala lima berada pada tingkat penguasaan 65-79 yang berarti bahwa tingkat perkembangan kognitif dalam mengenal lambang bilangan anak pada siklus I berada pada kriteria sedang.

Berdasarkan hasil penelitian tersebut, maka dapat diketahui bahwa tingkat perkembangan kognitif dalam mengenal lambang bilangan pada siklus satu masih berada pada kriteria sedang. Adapun kendala-kendala dan kekurangan penerapan model pembelajaran make a match pada siklus I adalah sebagai berikut. (1) Anak masih bingung dan tidak mentaati aturan yang telah disampaikan dalam menerapan model pembelajaran make a match. (2) Saat mennjukkan serta mencocokkan lambang bilangan, masih ada anak yang terbalik menunjukkan angka yang diminta.

Untuk mengatasi kendala-kendala tersebut, dalam melaksanakan siklus II akan dilakukan hal-hal sebagai berikut. (1) Menjelaskan kembali penerapan model pembelajaran make a match pada anak dengan menyampaikan setiap langkah yang harus diikuti secara berurutan. (2) Membimbing anak secara kelompok maupun individu yang belum memahami lambang bilangan dengan cara yang menyenangkan seperti bernyanyi dan bermain tebak-tebakan. 
Berdasarkan hasil refleksi tersebut, maka penelitian tindakan kelas ini perlu dilanjutkan ke siklus II untuk peningkatan dan penyempurnaan perkembangan kognitif dalam mengenal lambang bilagan pada anak kelompok A1 di TK Kartika VII-3 Singaraja.

Pada siklus II dilaksanakan mulai dari tanggal 02 Oktober 2018 sampai 05 Oktober 2018 yang dilaksanakan dalam 4 kali pertemuan. Pelaksanaan siklus II ini dilaksanakan berdasarkan hasil dari refleksi sikus I, membuat Rencana Pelaksanaan Pembelajaran Mingguan serta Rencana Pelaksanaan Pembelajaran Harian. Adapun tema pada siklus II ini adalah Tema Binatang.

Berdasarkan hasil analisis data yang disajikan dalam grafik polygon menunjukkan bahwa Mean < Median < Modus $(12,88<13<14)$, sehingga dapat dikatakan bahwa sebaran datadata perkembangan kognitif dalam mengenal lambang bilangan pada siklus II merupakan kurva juling negatif. Dengan demikian dapat diinterpretasikan bahwa skor perkembangan kognitif dalam mengenal lambang bilangan pada anak kelompok A1 di TK Kartika VII-3 Singaraja cenderung tinggi. Apabila disajikan dalam bentuk grafik polygon akan tampak sebagai berikut.

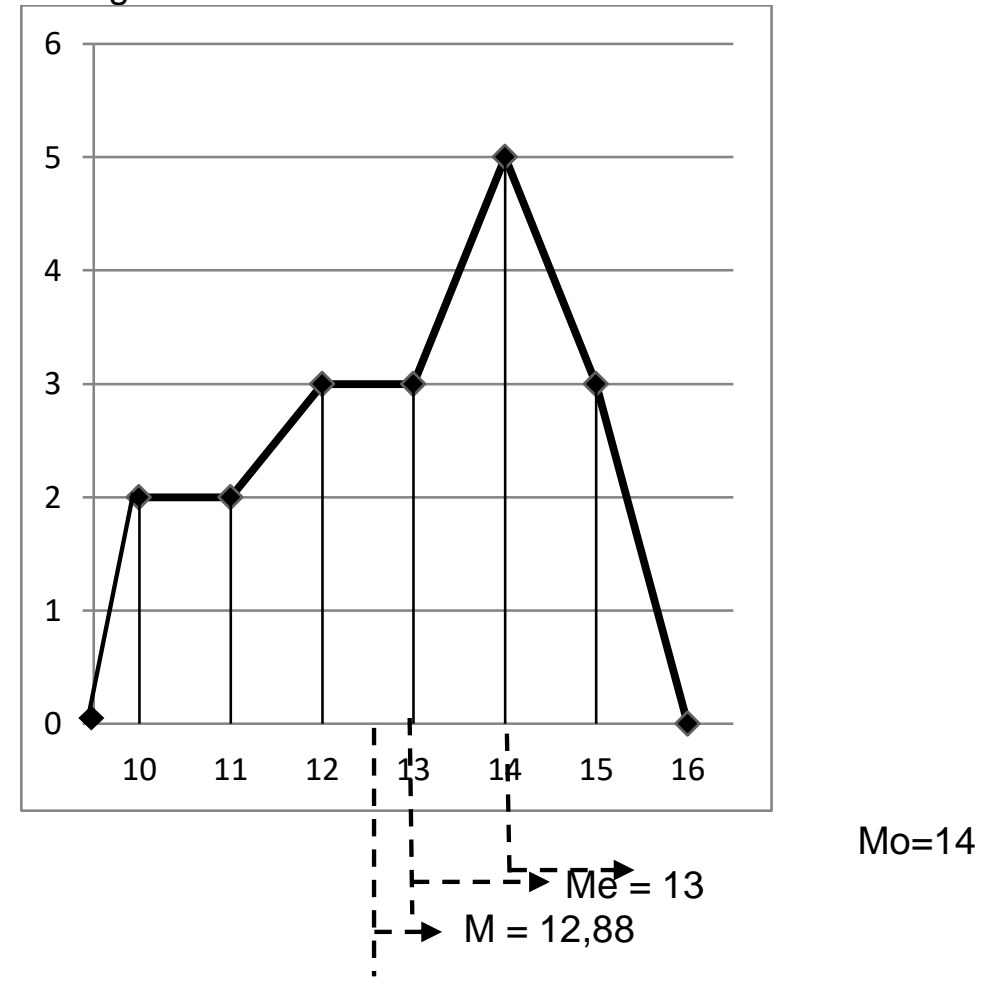

Gambar 4.2 Grafik Data Perkembangan kognitif dalam mengenal lambang bilangan Siklus II

Sedangkan untuk menghitung tingkat perkembangan kognitif dalam mengenal lambang bilangan anak dapat dihitung dengan membandingkan rata-rata persentase ( $\mathrm{M} \%$ ) dengan Kriteria Pedoman Acuan Patokan (PAP) skala lima. Nilai M\%=80,50\% yang dikonversikan kedalam PAP skala lima berada pada tingkat penguasaan 80-89 yang berarti bahwa tingkat perkembangan kognitif dalam mengenal lambang bilangan anak pada siklus II berada pada kriteria tinggi.

Setelah dilaksanakan perbaikan dari proses pembelajaran sikus I, dalam pelaksanaan siklus II terjadi peningkatan yang dapat dilihat pada perkembangan kognitif dalam mengenal lambang bilangan anak yang sebelumnya berada pada kriteria sedang meningkat menjadi 
kriteria tinggi. Adapun temuan-temuan yang diperoleh selama pelaksanaan siklus II adalah sebagai berikut. (1) Anak yang awalnya masih bingung dengan penerapan model pembelajaran make a match sudah dapat mengikuti setiap langkah penerapannya secara berurutan. (2) Anak yang awalnya kurang berkonsentrasi dalam melaksanakan kegiatan sudah dapat memusatkan perhatiannya. (3) Anak yang awalnya masih terbalik dalam menunjukkan dan mencocokkan lambang bilangan sudah dapat menunjukkan dengan benar. (4) Bimbingan serta motivasi tetap diberikan pada anak.

Secara umum proses pembelajaran dengan menggunakan model pembelajaran make a match untuk meningkatkan perkembangan kognitif dalam mengenal lambang bilangan anak kelompok A1 berlangsung sesuai dengan perencanaan dan telah mencapai indikator keberhasilan. Hal ini terlihat dari adanya peningkatan rata-rata persentase dari sikus I ke siklus II, sehingga penelitian ini tidak dilanjutkan ke siklus berikutnya.

\section{Pembahasan}

Berdasarkan hasil analisis data penelitian yang telah dilaksanakan dalam dua siklus menunjukkan terjadinya peningkatan perkembangan kognitif dalam mengenal lambang bilangan anak kelompok A1 TK Kartika VII-3 Singaraja dengan menerapkan model pembelajaran make a match. Setelah dilaksanakan tindakan pada siklus I diperoleh rata-rata persentase yaitu $65,25 \%$ pada kategori sedang menjadi $80,50 \%$ pada siklus II dengan kategori tinggi. Hal ini menunjukkan adanya peningkatan rata-rata persentase perkembangan kognitif dalam mengenal lambang bilangan anak dari siklus I ke siklus II mencapai 15,25\%.

Peningkatan ini dikarenakan penerapan model pembelajaran make a match sehingga terjadi peningkatan perkembangan kognitif dalam mengenal lambang bilangan. Hasil ini didukung oleh pendapat Rusman (2014:223) berpendapat bahwa, "keunggulan dari teknik ini adalah siswa mencari pasangan sambil belajar mengenai konsep atau topik dalam suasana menyenangkan." Hasil penelitian yang relevan dengan penelitian ini adalah penelitian yang dilakukan oleh Febryani (2015) yang berjudul Penerapan Metode Pembelajaran Make A Match Pada Anak Kelompok B Semester II Tahun Ajaran 2014/2015 di TK Dharma Sentana Candiksuma. Hal ini dapat dilihat dari adanya peningkatan rerata siklus I adalah $53,1 \%$ yang berada pada kategori rendah dan meningkat menjadi $80,62 \%$ dengan kriteria tinggi. Ada peningkatan kemampuan mengenal lambang bilangan pada anak TK Kelompok B di TK Dharma Sentana Candiksuma tahun pelajaran 2014/2015 sebesar 27,52\% setelah menggunakan metode make a match.

\section{Simpulan dan Saran}

Berdasarkan hasil analisis data dan pembahasan yang telah diuraikan dapat ditarik simpulan sebagai berikut. Terdapat peningkatan perkembangan kognitif dalam mengenal lambang bilangan pada anak kelompok A1 TK Kartika VII-3 Singaraja setelah diterapkan model pembelajaran make a match mencapai $15,25 \%$. Hal ini terlihat dari peningkatan persentase rata-rata perkembangan kognitif dalam mengenal lambang bilangan pada siklus I, M\%=65,25\% yang berada pada kategori sedang menjadi sebesar $80,50 \%$ pada siklus II yang berada pada kategori tinggi. Dengan demikian dapat disimpulkan bahwa penerapan model pembelajaran make a match dapat meningkatkan perkembangan kognitif dalam mengenal lambang bilangan anak kelompok A1 TK Kartika VII-3 Singaraja Tahun Pelajaran 2018/2019.

Berdasarkan simpulan tersebut, dapat diajukan saran - saran sebagai berikut. (1) Kepada guru, agar dapat semakin kreatif dalam menerapkan model pembelajaran yang akan digunakan untuk dapat meningkatkan perkembangan kognitif dalam mengenal lambang bilangan anak. (2) Kepada Kepala TK, agar dapat mengambil kebijakan yang paling tepat untuk membina guruguru disekolah yang dipimpinnya dalam menerapkan model pembelajaran yang dapat meningkatkan perkembangan anak. (3) Kepada penelitian lain, yang akan melakukan penelitian 
lebih lanjut terkait perkembangan kognitif dalam mengenal lambang bilangan dengan penelitian ini dapat dijadikan sebagai kajian penelitian yang relevan.

\section{Daftar Rujukan}

Arikunto, Suharsimi. dkk. 2015. Penelitian Tindakan Kelas. Jakarta: Bumi Aksara.

Carolin, Nike Adtya. 2014. Pengaruh model pembelajaran kooperatif Tipe Numbered Head Together Terhadap Kemampuan Mengena Konsep Bilangan 1-10 Kelompok A TK Dharma Wanita Tunas Muda. Universitas Negeri Surabaya, Volume 3, Nomor 3 (hlm. 2)

Dimyanti, Johni. 2013.Metodelogi Penelitian Pendidikan Dan Aplikasinya Pada Anak Usia Dini. Jakarta: Kencana Prenada Media Group.

Fadlillah, Muhammad. 2012. Desain Pembelajaran PAUD. Jogjakarta: AR-Ruzz Media.

Febryani, Putu Diah. 2015. Penerapan Metode Make A Match Untuk Meningkatkan Kemampuan Mengenal Lambang Bilangan Pada Anak Kelompok B Di TK Dharma Sentana Candiksuma. Universutas Pendidikan Ganesha. Volume 3, No.1

Hasan, lqbal. 2003. Pokok-pokok Materi Statistik 1. Jakarta: PT Bumi Aksara.

Kurniasih, Imas dan Berlin Sani. 2015. Ragam Pengembangan Model Pembelajaran untuk Peningkatan Profesionalitas Guru. Yogjakarta: Kata Pena.

Mulyasa. 2012. Manajemen PAUD. Bandung: PT Remaja Rosdakara.

Ngalimun. 2013. Strategi dan Model Pembelajaran. Yogyakarta: Aswaja Pressindo.

Rusman. 2014. Model-model Pembelajaran Edisi kedua. Jakarta: Rajawali Pers

Sanjaya, Wina. 2011. Penelitian Tindakan Kelas. Jakarta: Kencana Prenada Media Group.

Sukardi. 2012. Metodologi Penelitian Pendidikan Kompetensi dan Praktiknya. Jakarta: PT Bumi Aksara.

Tarigan, Daitin. 2006. Pembelajaran Matematika Realistik. Jakarta: Departemen Pendidikan Nasional Direktorat Jenderal Pendidikan Tinggi.

Trianto. 2011. Panduan Lengkap Penelitian Tindakan Kelas Teori \& Praktik. Jakarta: Prestasi Pustakaraya.

Wiyani, Ardi Novan. 2014. Bina Karakter Anak Usia Dini. Jogjakarta : Ar-rus Media.

Yusuf, Syamsu dan Nani Sugandhi. 2012. Perkembangan Peserta Didik. Jakarta: Rajawali Pers. 